\title{
Estimation of water use efficiency in the terrestrial ecosystems of the Yangtze River Delta region, China
}

\author{
Fan Wang ${ }^{1,2,3}$, Hong Jiang ${ }^{3, *}$, Min Cheng ${ }^{3}$, Linjing Zhang ${ }^{3}$, Jian Liu ${ }^{1,2}$, and Kunyong Yu ${ }^{1,2}$ \\ ${ }^{1}$ University Key Lab for Geomatics Technology and Optimize Resources Utilization in Fujian Province, Fujian Agriculture and \\ Forestry University, Fuzhou, China \\ ${ }^{2}$ College of Forestry, Fujian Agriculture and Forestry University, Fuzhou, China \\ ${ }^{3}$ Jiangsu Provincial Key Laboratory of Geographic Information Science and Technology, International Institute for Earth System \\ Science, Nanjing University, Nanjing, China
}

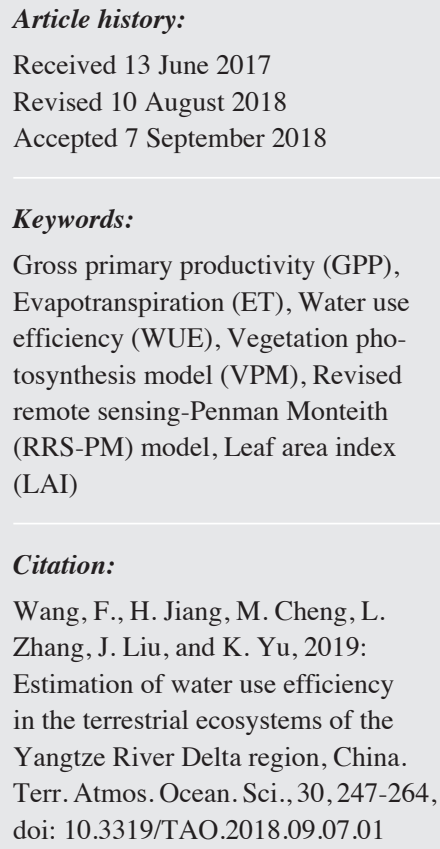

\begin{abstract}
Understanding the characteristics of water use efficiency (WUE) could enhance our understanding of the integrated response of terrestrial ecosystems to climate change. In this study, the vegetation photosynthesis model (VPM) and the revised remote sensing-Penman Monteith (RRS-PM) model were used to characterize the spatial-temporal dynamics of gross primary productivity (GPP) and evapotranspiration (ET) in the Yangtze River Delta (YRD) region. Our predicted GPP and ET results were in the range of those reported by other models. To be specific, the RRS-PM model could explain $85 \%$ of the variability in ET at the Anji site, China. The root mean square error between the simulation value and the measured ET was $8.543 \mathrm{~mm}$ $\mathrm{month}^{-1}$. For the evergreen broadleaf forest, deciduous needle leaf forest and deciduous broadleaf forest, GPP decreased and ET increased, thus the WUE $=($ GPP/ET $)$ inevitably decreased. The increase in WUE in grassland was due to the decreased ET, for which the rate of decrease was greater than for GPP. For the spatial distribution of WUE, the maximum value occurred in the southern and northeastern parts of the YRD region, while the minimum value was distributed in the middle and northwest. This is likely due to the different land-cover types. In the south, there is more forest, while in the north the land-cover type is almost entirely cropland. In our study, GPP increased with increasing LAI across all of the plant function types. However, ET only increased with LAI when LAI was less than $2 \mathrm{~m}^{2} \mathrm{~m}^{-2}$ across all of the plant function types, once LAI was larger than $2 \mathrm{~m}^{2} \mathrm{~m}^{-2}$, ET did not continue to increase with LAI.
\end{abstract}

\section{INTRODUCTION}

Terrestrial ecosystem gross primary productivity (GPP) is a quantitative description of the amount of carbon fixed by the vegetation and is at the beginning of the carbon biogeochemical cycle. In the study of the carbon cycle, GPP has been an important indicator (Zhao and Running 2010). Freshwater resources are unevenly distributed around the world and in areas of water shortage regional development is restricted, even threatening normal life for some populations. The water cycle is the basis of replenishment of freshwater resources in nature, and it is only by fully understanding each process in the water cycle, that crises in the supply of fresh water

\footnotetext{
* Corresponding author

E-mail: jianghong_china@hotmail.com
}

are likely to be resolved. Studies have shown that more than half of all precipitation falling on land surfaces returns to the atmosphere by the terrestrial ecosystem evapotranspiration (ET). Thus, the terrestrial ecosystem ET plays an important role in the global water cycle (Mu et al. 2011).

The carbon and water cycles are closely related in the terrestrial ecosystem because the exchange of carbon dioxide and water vapour between biosphere and atmosphere are both controlled by stomata (Beer et al. 2009). Water use efficiency (WUE), the ratio of gross primary productivity (GPP) to evapotranspiration (ET), can be used to quantify this coupling relationship (Yu et al. 2004; Tang et al. 2014; Wang et al. 2015; Zhu et al. 2015). Therefore, to use the rare and precious water resources efficiently and reasonably, it 
is essential to understanding the characteristics of GPP, ET, WUE, and their relationship with related driving factors. Meanwhile, understanding the GPP, ET, WUE characteristics, and their relationship with related factors can greatly enhance our knowledge of their control processes as well as the adaptation mechanism of carbon and water cycle to climate change (Wang et al. 2016).

In recent years, eddy-covariance (EC) flux tower networks have provided an opportunity to quantify WUE at the ecosystem scale (Reichstein et al. 2007). However, to estimate WUE at the regional or global scale, there is a huge challenge when using flux observations only. To date, two methods exist for evaluating carbon and water fluxes at the large scale. First, by using a process-based ecosystem model, they can be simulated (Zhu et al. 2011; Ito and Inatomi 2012). Second, remote sensing models can be used for regional- and global-scale carbon and water fluxes estimation (Xiao et al. 2004a; Wang et al. 2015). Remote sensing models are of small calculation and a strong theoretical basis, which have become an important means of simulating terrestrial ecosystem carbon and water fluxes at regional scale. GPP is quantified as a function of light use efficiency and climatic factors (Xiao et al. 2004a), while ET is calculated based on the Penman-Monteith equation (Cleugh et al. 2007).

Taking one of China's most developed, dynamic, densely populated, and concentrated industrial areas, the Yangtze River Delta (YRD) region as a study area, the primary objectives of the work described in this paper were (1) to explore the spatial-temporal characteristics of GPP, ET, and WUE in the terrestrial ecosystems of the YRD region; and (2) to quantify the relationship of GPP, ET in the terrestrial ecosystems with their biotic variable, namely leaf area index.

\section{MATERIALS AND METHODS}

\subsection{Description of the Study Area}

The center of the Yangtze River Delta (YRD) region is located at $30.5^{\circ} \mathrm{N}$ and $120.5^{\circ} \mathrm{E}$. The study area has a typical subtropical monsoon climate with a warm and humid summer and a cold and dry winter. The annual mean air temperature (Ta) and mean precipitation (PPT) are $15.7^{\circ} \mathrm{C}$ and $1158 \mathrm{~mm}$, respectively (Wu et al. 2014). Specifically, from late June to early July, it is persistently overcast with rain in this region. The major forest type is subtropical evergreen broadleaf forest (Fig. 1).

The spatial-temporal dynamics of GP ET and WUE in

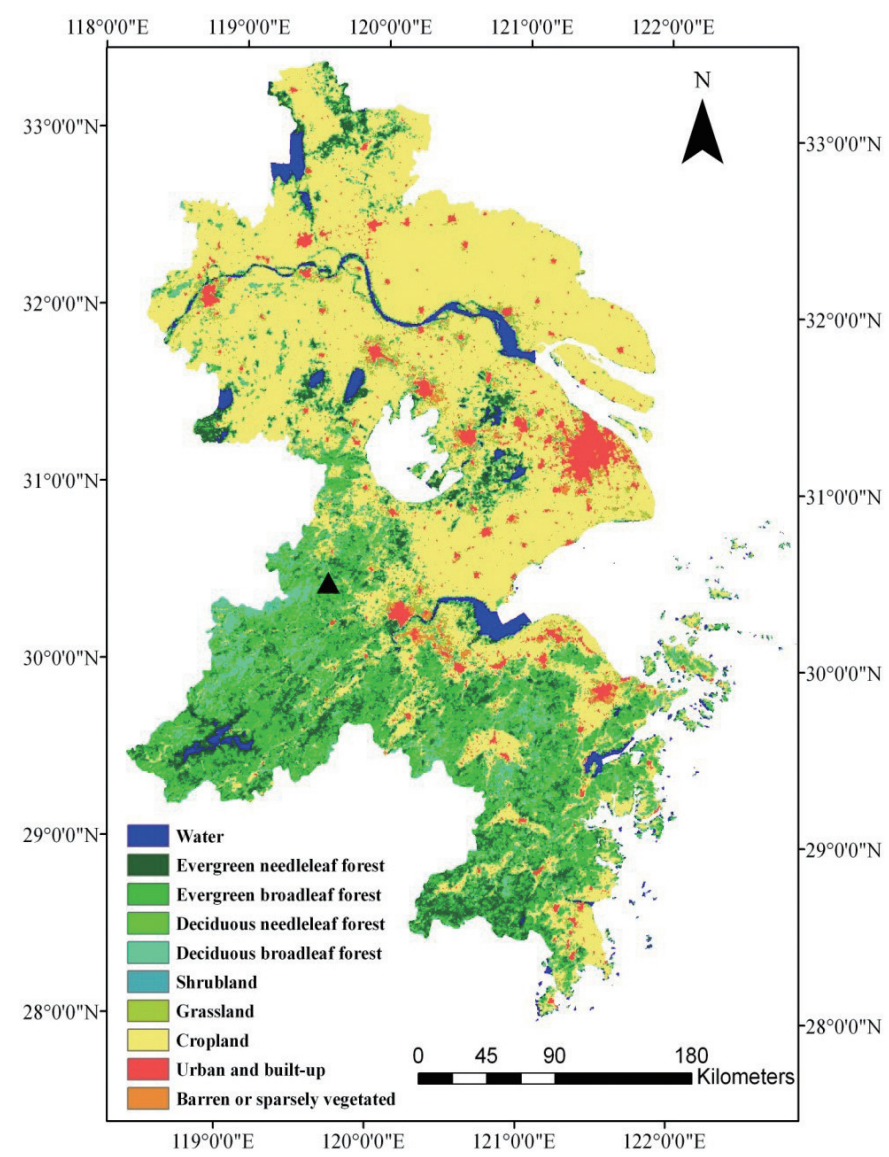

Fig. 1. 2013 spatial distribution of land-use/cover type in the Yangtze River Delta. 
the YRD region over the period 2001 - 2014 were characterized. Water flux data observed during 2012 - 2014 at the Anji site $\left(30.47^{\circ} \mathrm{N}, 119.67^{\circ} \mathrm{E}\right)$ was used to conduct the precision evaluation of the ET estimated by the remote sensing model.

\subsection{The Vegetation Photosynthesis Model (VPM)}

\subsubsection{Description of the VPM Model}

Based on the assumption that nonphotosynthetically active vegetation within a canopy makes no contribution to GPP, the VPM model revises the light use efficiency model as:

$\mathrm{GPP}=\varepsilon \times \mathrm{FPAR}_{\mathrm{PAV}} \times \mathrm{PAR}$

where $\mathrm{FPAR}_{\mathrm{PAV}}$ is the fraction of photosynthetically active radiation (PAR) absorbed by leaf chlorophyll in the canopy, PAR is the photosynthetically active radiation ( $\mu \mathrm{mol}$ photosynthetic photon flux density, PPFD), and $\varepsilon$ is the light use efficiency ( $\mu \mathrm{mol} \mathrm{CO}_{2} / \mu \mathrm{mol}$ PPFD) which is affected by temperature, water, and leaf phenology:

$\varepsilon=\varepsilon_{\text {max }} \times \mathrm{T}_{\text {scalar }} \times \mathrm{W}_{\text {scalar }} \times \mathrm{P}_{\text {scalar }}$

where $\varepsilon_{\max }$ is the maximum light use efficiency and $\mathrm{T}_{\text {scalar }}$, $\mathrm{W}_{\text {scalar }}$, and $\mathrm{P}_{\text {scalar }}$ are used to quantify the effects of temperature, water and leaf phenology on light use efficiency of vegetation, respectively. For details of the VPM model, one can refer to Xiao et al. (2004a).

\subsubsection{Estimation of Model Parameters}

\subsubsection{Estimation of the Maximum Light Use Efficiency}

The maximum light use efficiency can be obtained from an analysis of the net ecosystem exchange (NEE)-PPFD relationship at flux tower sites or from a survey of the literature (Ruimy et al. 1995). The relationship between NEE and PPFD can be fitted with a linear or Michaelis-Menten function. In this study, a literature survey was conducted to collect the maximum light use efficiency determined by the Michaelis-Menten function. For each vegetation type, the average of the maximum light use efficiency was used to estimate the GPP (Table 1).

\subsubsection{Estimation of $T_{\min }, T_{o p t}$, and $T_{\max }$}

In calculation of Tscalar, the minimum, maximum and optimal temperature for photosynthetic activities $\left(T_{\min }, T_{\text {opt }}\right.$, and $\mathrm{T}_{\max }$ ) vary among different vegetation types. A literature survey was conducted to gather the values of different vegetation types (Table 2).

\subsection{The Revised Remote Sensing - Penman Monteith (RRS-PM) Model}

\subsubsection{Description of the RRS-PM Model}

Based on the model proposed by Mu et al. (2007), Yuan et al. (2010) developed the RRS-PM model. Compared with the former, there are 2 changes in the RRS-PM model. One is the equations dealing with the temperature constraint for stomatal conductance, the other is the equations' computing energy allocation between vegetation canopy and soil surface. In RRS-PM model, ET is composed of vegetation transpiration ( $\mathrm{Tr}$ ) and soil evaporation (E). The full description of the RRS-PM model is provided as follows.

Penman-monteith (PM) formula was used to calculate vegetation transpiration:

$\mathrm{T}_{\mathrm{r}}=\frac{\Delta \times \mathrm{A}_{\mathrm{c}}+\rho \times \mathrm{C}_{\mathrm{p}} \times\left(\mathrm{e}_{\mathrm{s}}-\mathrm{e}\right) / \mathrm{r}_{\mathrm{a}}}{\lambda \times\left[\Delta+\gamma \times\left(1+\mathrm{r}_{\mathrm{s}} / \mathrm{r}_{\mathrm{a}}\right)\right]}$

where $\Delta$ is the slope of the curve relating the saturated water vapour pressure $\left(\mathrm{e}_{\mathrm{s}}\right)$ to the temperature, $\mathrm{A}_{\mathrm{c}}$ is solar radiation received by the canopy, $\varrho$ is the air density, $\mathrm{C}_{\mathrm{p}}$ is the specific heat capacity of the air, e is the actual water vapour pressure, $\gamma$ is the psychrometric constant, $r_{a}$ is the aerodynamic resistance, $\gamma$ is the psychrometric constant, and $r_{s}$ is the surface resistance.

$\mathrm{Ac}=\mathrm{Rn}-\mathrm{As}=\mathrm{Rn}-\mathrm{Rn} \times \mathrm{e}^{-\mathrm{k}} \times \mathrm{LAI}$

where $\mathrm{Rn}$ is net radiation, As is the solar radiation received by the soil surface, $\mathrm{k}$ is the extinction coefficient, the value is 0.5 , and LAI is the leaf area index.

$$
\begin{aligned}
& \mathrm{r}_{\mathrm{s}}=\frac{1}{\mathrm{c}_{1} \times \mathrm{m}(\mathrm{T}) \times \mathrm{m}(\mathrm{VPD}) \times \mathrm{LAI}} \\
& \mathrm{m}(\mathrm{T})=\mathrm{e}^{\left[-\left(\frac{\mathrm{T}-\mathrm{T}_{\text {or }}{ }^{2}}{\mathrm{~T}_{\text {opt }}}\right)^{2}\right]}
\end{aligned}
$$

$\mathrm{m}(\mathrm{VPD})= \begin{cases}1.0 & \mathrm{VPD} \leq \mathrm{VPD}_{\text {open }} \\ \frac{\mathrm{VPD}_{\text {close }}-\mathrm{VPD}}{\mathrm{VPD}_{\text {close }}-\mathrm{VPD}_{\text {open }}} & \mathrm{VPD}_{\text {open }} \leq \mathrm{VPD} \leq \mathrm{VPD}_{\text {close }} \\ 0.1 & \mathrm{VPD} \geq \mathrm{VPD}_{\text {close }}\end{cases}$

where $C_{1}$ is the maximum stomatal conductance of the unit leaf area, $\mathrm{T}$ is air temperature, $\mathrm{T}_{\mathrm{opt}}=25^{\circ} \mathrm{C}$, VPD is the saturation vapor pressure deficit, $\mathrm{VPD}_{\text {open }}$ and $\mathrm{VPD}_{\text {close }}$ is the value of VPD corresponding to the stoma is unrestricted and value of VPD corresponding to the stoma is completely restricted.

The soil evaporation was obtained by combining the potential soil evaporation with the soil moisture restriction 
equation [Eqs. (8) - (11)]:

$\mathrm{E}_{\mathrm{p}}=\frac{\Delta \times \mathrm{A}_{\mathrm{s}}+\rho \times \mathrm{C}_{\mathrm{p}} \times\left(\mathrm{e}_{\mathrm{s}}-\mathrm{e}\right) / \mathrm{r}_{\mathrm{sa}}}{\lambda \times\left(\Delta+\gamma \times \frac{\mathrm{r}_{\mathrm{tot}}}{\mathrm{r}_{\mathrm{sa}}}\right)}$

$r_{s a}=\frac{r_{r} \times r_{\text {rot }}}{r_{r}+r_{r o t}}$

$r_{r}=\frac{\rho \times C_{p}}{4.0 \times \sigma \times T^{3}}$

$\mathrm{E}=\mathrm{E}_{\mathrm{p}} \times\left(\frac{\mathrm{RH}}{100}\right)^{\left(\mathrm{e}_{\mathrm{s}}-\mathrm{e}\right) / 100}$

where $E_{p}$ is the potential soil evaporation, $E$ is the soil evaporation, $\mathrm{r}_{\mathrm{sa}}$ is the aerodynamic resistance $\left(\mathrm{s} \mathrm{m}^{-1}\right), \mathrm{r}_{\mathrm{r}}$ is resis- tance to radiative heat transfer $\left(\mathrm{s} \mathrm{m}^{-1}\right), \mathrm{r}_{\text {tot }}$ is the total aerodynamic resistance to vapor transport, $\sigma$ is the boltzmann constant, RH is the relative humidity.

\subsubsection{Parameterization of the RRS-PM Model}

In this study, the values of the vapor pressure deficit (VPD) corresponding to full stomatal closure $\left(\mathrm{VPD}_{\text {close }}\right)$, the mean potential stomatal conductance per unit leaf area $\left(\mathrm{C}_{1}\right)$, and the total aerodynamic conductance to vapor transport $\left(\mathrm{C}_{\mathrm{tot}}\right)$ were derived from the results of Xu et al. (2013). In their study, the values of parameters were determined by nonlinear curve fitting. First the initial parameter values and their bounds were determined. When the value of a parameter could not be fitted, a parameter value obtained from previous studies was assigned (Yuan et al. 2007; Mu et al. 2011), and then the nonlinear regression was run again. Finally, the values of $\mathrm{VPD}_{\text {close }}, \mathrm{C}_{1}$, and $\mathrm{C}_{\text {tot }}$ were $5209 \mathrm{~Pa}$,

Table 1 . The maximum value of light use efficiency $\left(\varepsilon_{\max }, \mu\right.$ mol $\mathrm{CO}_{2} / \mu \mathrm{mol}$ PPFD) for different biomes. ENF: evergreen needle-leaf forest; EBF: evergreen broadleaf forest; DNF: deciduous needle-leaf forest; DBF: deciduous broadleaf forest; GRA: grassland; CRO: cropland.

\begin{tabular}{c|cccccc}
\hline References & ENF & EBF & DNF & DBF & GRA & CRO \\
\hline This study & 0.04375 & 0.045 & 0.04375 & 0.04363 & 0.02072 & 0.0633 \\
Xiao et al. (2004a) & 0.040 & & & & & \\
Wang et al. (2010) & 0.0475 & & & & & \\
Xiao et al. (2005) & & 0.045 & & & & \\
Xiao et al. (2004b) & & & 0.044 & & \\
Wang et al. (2010) & & & 0.0326 & & \\
Wang et al. (2010) & & & 0.0543 & & \\
Wu et al. (2008) & & & & 0.0167 & \\
Wu et al. (2008) & & & & 0.0248 & \\
Wu et al. (2008) & & & & 0.0054 & \\
Wang et al. (2010) & & & & 0.0249 & \\
Liu et al. (2011) & & & & 0.0299 & \\
Liu et al. (2011) & & & & & 0.0226 & \\
Yan et al. (2009) & & & & & & \\
\hline
\end{tabular}

Table 2. The values of $\mathrm{T}_{\min }, \mathrm{T}_{\mathrm{opt}}$, and $\mathrm{T}_{\max }$ for different biomes.

\begin{tabular}{ccccc}
\hline Biomes & $\mathbf{T}_{\min }$ & $\mathbf{T}_{\text {opt }}$ & $\mathbf{T}_{\max }$ & References \\
\hline ENF & 0 & 20 & 40 & Xiao et al. (2004a) \\
EBF & 2 & 28 & 48 & Xiao et al. (2005) \\
DNF & -10 & 25 & 35 & Chen et al. (2014) \\
DBF & -1 & 20 & 40 & Xiao et al. (2004b) \\
GRA & 6 & 17 & 21 & Wu et al. (2008) \\
CRO & 0 & 24.8 & 50 & Liu et al. (2014) \\
\hline
\end{tabular}


$0.00149 \mathrm{~m} \mathrm{~s}^{-1}, 0.0039 \mathrm{~m} \mathrm{~s}^{-1}$, respectively.

\subsection{Model Inputs}

The model inputs mainly included land surface water index (LSWI), enhanced vegetation index (EVI), land-use/ cover data, leaf area index, air temperature, and photosynetically active radiation (PAR). As MODIS does not provide LSWI products, $500 \mathrm{~m}$ surface reflectance was used to calculate the LSWI. The 8-day MODIS products were composited into monthly data using a maximum value composite method (Holben 1986). Combined with the monthly EVI and yearly land cover data, all MODIS products were downloaded at the same website (http://ladsweb.nascom. nasa.gov/data/search.html). The Global LAnd Surface Satellite (GLASS) LAI, produced by the general regression neural networks (GRNNs) method, has demonstrated that the quality of GLASS-LAI data has been greatly improved (Xiao et al. 2013; Xiang et al. 2014). GLASS-LAI data with a temporal resolution of 8 days were obtained from the Center for Global Change Data Processing and Analysis of Beijing Normal University (http://glass-product.bnu.edu.

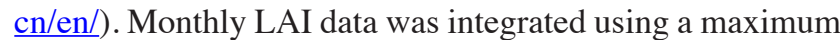
value composite method (Holben 1986). In our study, we downloaded NASA's Modern ERA- Retrospective Analysis for Research and Applications of Global Modeling and Assimilation (MERRA) monthly products as meterological inputs (http://gmao.gsfc.nasa.gov/research/merra/).

\subsection{Field Measurements and Data Processing}

Water flux was measured with EC systems consisting of open-path infrared gas analyzers (Li-7500; Licor Inc., Lincoln, NB, USA) and a 3-D sonic anemometer (CSAT3; Campbell Scientific Inc., Logan, UT, USA). The EC systems were mounted $38 \mathrm{~m}$ above ground at AJ. A data logger (CR1000; Campbell Scientific Inc., Logan, UT, USA) recorded the EC signals at $10 \mathrm{~Hz}$ for archiving and on-line turbulence statistics computation.

2-D coordination rotation and Webb Pearman-Leuning correction were applied to obtain half-hourly mean water vapor flux. All abnormal data, caused by instrument malfunctions and weather effects, such as rain and dew, were deleted. Missing data of less than $2 \mathrm{hrs}$ were filled using linear interpolation. Large gaps (more than $2 \mathrm{hrs)} \mathrm{were} \mathrm{filled}$ using the mean diurnal variation method. The monthly value of both fluxes was integrated from the half-hourly data.

\section{RESULTS AND DISCUSSION}

\subsection{Assessment on the VPM Model}

We compared the results simulated by the VPM model with those reported in the literature (Table 3). Table 3 indicates that our results were in the range of those reported by other models except that GPP of grassland in this study was much higher. The difference between GPP of grassland predicted by different models was mainly due to the different climate conditions across the different study areas (Table 4). The YRD area has a typical subtropical monsoon climate, and therefore the grassland in this area has a relatively higher productivity. When we compared the results to flux measurements with similar climate conditions, the VPM results were in the range of the flux observations (Table 3).

\subsection{Assessment on the RRS-PM Model and the WUE}

Water vapor flux data during 2012 - 2014 at the Anji site was used for the validation of the RRS-PM model. Two statistical indicators (the determination coefficient and root mean square error) were chosen for the assessment of the RRS-PM model. The results showed that the RRS-PM model could simulate the value and seasonal variation of ET at the flux site (Fig. 2). To be specific, the RRS-PM model could explain $86 \%$ of the variability in ET, the root mean square error between the simulation value and the measurement was $8.543 \mathrm{~mm} \mathrm{month}^{-1}$ (Fig. 3).

Subsequently, we compared the ET and WUE results in this study with those reported in the literature (Tables 5 and 6). According to the literature, the ET of the evergreen needle leaf forest, evergreen broadleaf forest, deciduous broadleaf forest, grassland and cropland ranged from 510 - 822, 630 - 905, 581 - 957, 451 - 681, and 486 - $688 \mathrm{~mm} \mathrm{a}^{-1}$, respectively. According to the literature, the WUE of the evergreen needle leaf forest, evergreen broadleaf forest, deciduous needle leaf forest, deciduous broadleaf forest, grassland and cropland ranged from 0.52 - 3.66, $1.88-3.51,1.29-1.68,1.36-2.57,0.41-1.90$, and 1.57 $-4.02 \mathrm{~g} \mathrm{C} \mathrm{kg}^{-1} \mathrm{H}_{2} \mathrm{O}$, respectively. Our modeled ET and WUE were in the range of the results reported in the literature.

\subsection{Temporal and Spatial Variations of GPP}

From $2001-2014$, GPP in all vegetation types in the YRD region showed a decline trend, but at different rates (Fig. 4). GPP in deciduous broadleaf forest and grassland exhibited greater decreasing trends than other vegetation types. In contrast, GPP in cropland only decreased slightly due to human disturbance minimizing the impact of climate change. In general, the regional GPP also showed decreasing trends. This result was consistent with that of other studies. Zhao and Running (2010) explored the temperal and spatial variations of NPP in global terrestrial ecosystems during 2001 - 2009 using MODIS products. They pointed out that GPP in some parts of Southern China exhibited a decreasing tendency. Liu (2013) analyzed the temporal and spatial variations of NPP in terrestrial ecosystems in China during 2000 - 2010 using the BEPS model. Their results showed that NPP in terrestrial ecosystems in the YRD region also 
showed a decreasing trend. This was mainly caused by global climate change, the frequency of summer droughts has increased in this region, and severe summer droughts have led to a decline in vegetation productivity (Zhao and Running 2010; Wang et al. 2016). Along with freezing rain and ice storms, GPP in the YRD region has gradually shown a decreasing trend (Xu et al. 2013).

Figure 4 illustrates the spatial distribution of GPP during the study period. The value of GPP was higher in the south and northwestern YRD than in any other part of the YRD region. In general, GPP was higher in the south (Fig. 5). This is likely to be due to the different land-cover types. In the south, there is more forest, while in the north the land-cover type is almost entirely cropland (Wang et al. 2015). Forest ecosystems can maintain a high photosynthetic capacity for a long time in a year compared to cropland ecosystems, and as a result, the forest ecosystems fix more carbon dioxide.

\subsection{Temporal and Spatial Variations of ET}

During the study period, ET for all vegetation types in the YRD region showed different trends (Fig. 6). ET in forest ecosystems all showed an increasing tendency, with evergreen broadleaf forest increasing the most significantly. In contrast, ET in cropland and grassland both showed a decreasing trend, with the latter having a higher decreasing rate. In general, the regional ET showed an increasing trend.

By far, the results of the variation trend of ET in the YRD region were inconsistent. In the study of Liu (2013), ET in terrestrial ecosystems in southeast China from 2000 - 2010 showed an increasing trend. Jung et al. (2010) and Tian et al. (2012) achieved a similar conclusion. In contrast, based on the terrestrial water balance equation, Zeng et al. (2012) found a decreasing trend in ET in terrestrial ecosystems in southeast China from 2000 - 2010. Wang et al. (2015) suggested that ET in terrestrial ecosystems in the YRD region from 2001 - 2012 also showed a dereasing trend. The discrepancy in the results of the variation trend of ET was likely caused by an inconsistency in the research method, study period, study area and the driving forces. This indicates that more studies need to be conducted by modifying the model, adding the ground-based measurement and improving the accuracy of the driving data. For the spatial distribution of ET, the maximum value of ET occurred in the south and northeastern part of the YRD region (Fig. 7).

Table 3. Comparison of simulated annual mean GPP in this study against previous results among different biomes.

\begin{tabular}{|c|c|c|c|c|c|c|c|}
\hline & Study period & CRO & ENF & $\mathbf{E B F}$ & DNF & DBF & GRA \\
\hline \multicolumn{8}{|c|}{ The results of model simulation } \\
\hline This study & $2001-2014$ & 1143 & 1222 & 1747 & 1084 & 1666 & 1026 \\
\hline Li et al. (2013) & $2000-2009$ & 839 & 992 & 1430 & 829 & 1083 & 382 \\
\hline Chen et al. (2014) & $2006-2008$ & 1000 & 954 & 1203 & 650 & 1045 & 210 \\
\hline Feng et al. (2007) & 2001 & 872 & 938 & 1480 & 844 & 998 & 245 \\
\hline Liu (2013) & $2000-2010$ & 1168 & 1106 & 1620 & 770 & 1282 & 220 \\
\hline Gao and Liu (2008) & $1982-2003$ & 724 & 928 & 1122 & 996 & 1030 & 490 \\
\hline Li (2004) & 2001 & 730 & 1042 & 1126 & 728 & 852 & 378 \\
\hline Gao and Liu (2008) & $1982-2003$ & 744 & 1172 & 2172 & 1314 & 1130 & 356 \\
\hline Wang (2004) & 2001 & 1484 & 740 & 1510 & 890 & 1648 & 489 \\
\hline Yan et al. (2009) & $2003-2004$ & 1686 & & & & & \\
\hline \multicolumn{8}{|c|}{ The measurements } \\
\hline Yan et al. (2009) & $2003-2004$ & 1770.6 & & & & & \\
\hline Chen et al. (2015) & $2007-2009$ & 2205.5 & & & & & \\
\hline Zhou et al. (2011) & $2003-2005$ & & & 1446.5 & & & \\
\hline Liu et al. (2009) & $2006-2009$ & & & & & 1434.4 & \\
\hline Wei et al. (2012b) & $2005-2006$ & & & & & 2166.2 & \\
\hline Xiao et al. (2004a) & $1998-2001$ & & 1467 & & & & \\
\hline Gilmanov et al. (2007) & $2004-2005$ & & & & & & 528 \\
\hline Hirata et al. (2013) & $2005-2007$ & & & & & & 1143.4 \\
\hline Gilmanov et al. (2007) & 2003 & & & & & & 1083.8 \\
\hline
\end{tabular}


Table 4. Description of flux sites used for the validation of VPM results.

\begin{tabular}{ccccccc}
\hline Sites & Latitude & Altitude & Vegetation types & $\begin{array}{c}\text { Annual mean } \\
\text { temperature }\end{array}$ & $\begin{array}{c}\text { Annual mean } \\
\text { precipitation }\end{array}$ & Reference \\
\hline Yucheng (China) & $36^{\circ} 57^{\prime}$ & 23 & Winter wheat, corn & 13.1 & 528 & Yan et al. (2009) \\
Shouxian (China) & $32^{\circ} 33^{\prime}$ & 26.8 & Winter wheat, rice & 15 & 900 & Chen et al. (2015) \\
Howland forest (USA) & $45^{\circ} 12^{\prime}$ & - & ENF & 6.7 & - & Xiao et al. (2004a) \\
Dinghushan (China) & $23^{\circ} 10^{\prime}$ & 300 & EBF & 22.3 & 1678 & Zhou et al. (2011) \\
Daxing (China) & $39^{\circ} 31^{\prime}$ & 30 & DBF & 11.5 & 569 & Liu et al. (2009) \\
Yueyang (China) & $29^{\circ} 19^{\prime}$ & 31 & DBF & 16.8 & 1309 & Wei et al. (2012b) \\
Tojal (Portugal) & $38^{\circ} 28^{\prime}$ & 190 & GRA & 14.6 & 387 & Gilmanov et al. (2007) \\
Nakashibetsu (Japan) & $43^{\circ} 32^{\prime}$ & 50 & GRA & 5.6 & 1160 & Hirata et al. (2013) \\
Lelystad (Netherlands) & $52^{\circ} 30^{\prime}$ & 0 & GRA & 10 & 780 & Gilmanov et al. (2007) \\
\hline
\end{tabular}

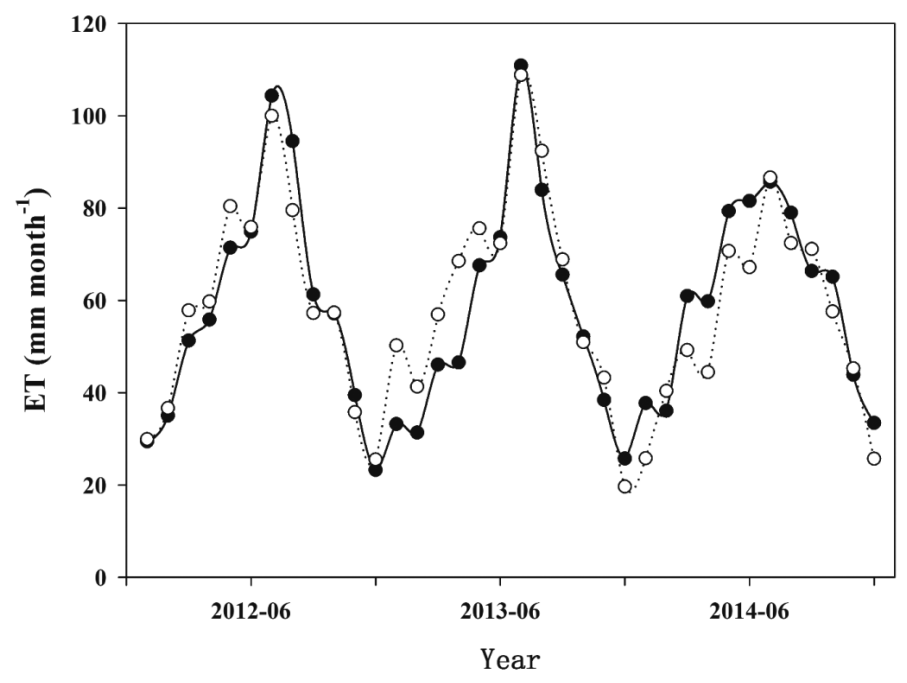

Fig. 2. Comparison of monthly mean evapotranspiration (ET) estimated by the RRS-PM against measured ET at the Anji eddy-covariance site from 2012 - 2014. The filled circle dots represent predicted ET, and the open circle dots represent observed ET.

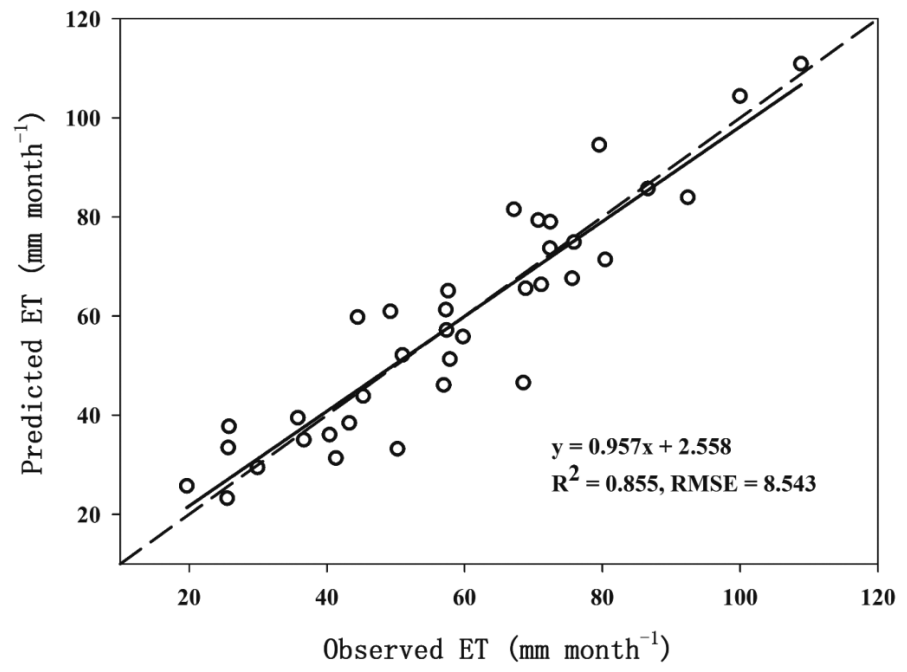

Fig. 3. RRS-PM against measured ET at the Anji eddy-covariance site. The dashed line is the 1:1 line and the solid line is the regression line. 
Table 5. Comparison of simulated annual mean ET in this study against previous results among different biomes.

\begin{tabular}{cccc}
\hline Vegetation function types & Study period & ET $\left(\mathbf{m m ~ a}^{-1}\right)$ & References \\
\hline \multirow{2}{*}{ evergreen needle leaf forest } & $2001-2014$ & 751 & This study \\
& $2003-2008$ & $510-822$ & Wei et al. (2012a) \\
\hline \multirow{3}{*}{ evergreen broadleaf forest } & $2001-2014$ & 817 & This study \\
& $2003-2005$ & 630 & Zhou et al. (2011) \\
& $1982-2006$ & 905 & Zhang et al. (2010) \\
\hline deciduous needle leaf forest & $2001-2014$ & 780 & This study \\
\hline \multirow{3}{*}{ deciduous broadleaf forest } & $2001-2014$ & 769 & This study \\
& $2005-2006$ & 957 & Wei et al. (2012b) \\
& $2006-2009$ & 581 & Kang et al. (2016) \\
\hline \multirow{2}{*}{ grassland } & $2001-2014$ & 603 & This study \\
& $2003-2011$ & $451-681$ & Zheng et al. (2013) \\
\hline \multirow{2}{*}{ cropland } & $2001-2014$ & 655 & This study \\
& $2004-2005$ & $486-688$ & Wu et al. (2006) \\
\hline \multirow{2}{*}{} & 2009 & 671 & Zhao and Ji (2010) \\
\hline
\end{tabular}

Table 6. Comparison of WUE for various biomes in this study with those reported in the literature.

\begin{tabular}{|c|c|c|}
\hline Vegetation function types & WUE $\left(\mathrm{g} \mathrm{C} \mathrm{kg}^{-1} \mathrm{H}_{2} \mathrm{O}\right)$ & References \\
\hline \multirow{5}{*}{ evergreen needle leaf forest } & 1.63 & This study \\
\hline & 1.70 & Wang et al. (2015) \\
\hline & $0.52-3.66$ & Buchmann and Schulze (1999) \\
\hline & 0.95 & Kuglitsch et al. (2008) \\
\hline & 2.53 & Yu et al. (2008) \\
\hline \multirow{4}{*}{ evergreen broadleaf forest } & 2.14 & This study \\
\hline & 1.95 & Wang et al. (2015) \\
\hline & 1.88 & Yu et al. (2008) \\
\hline & $2.82-3.51$ & Beer et al. (2009) \\
\hline \multirow{3}{*}{ deciduous needle leaf forest } & 1.39 & This study \\
\hline & 1.68 & Wang et al. (2015) \\
\hline & 1.29 & Buchmann and Schulze (1999) \\
\hline \multirow{5}{*}{ deciduous broadleaf forest } & 2.17 & This study \\
\hline & 1.87 & Wang et al. (2015) \\
\hline & 1.83 & Buchmann and Schulze (1999) \\
\hline & 1.36 & Kuglitsch et al. (2008) \\
\hline & 2.57 & Yu et al. (2008) \\
\hline \multirow{8}{*}{ grassland } & 1.70 & This study \\
\hline & 1.66 & Wang et al. (2015) \\
\hline & $1.51-1.65$ & Buchmann and Schulze (1999) \\
\hline & 1.90 & Wever et al. (2002) \\
\hline & 1.73 & Ponton et al. (2006) \\
\hline & $0.41-1.26$ & Hu et al. (2008) \\
\hline & 1.47 & Li et al. (2008) \\
\hline & $1.53-2.27$ & Schymanski et al. (2008) \\
\hline \multirow{4}{*}{ cropland } & 1.74 & This study \\
\hline & 1.61 & Wang et al. (2015) \\
\hline & $1.57-4.02$ & Beer et al. (2009) \\
\hline & $1.83-2.02$ & Tong et al. (2009) \\
\hline
\end{tabular}




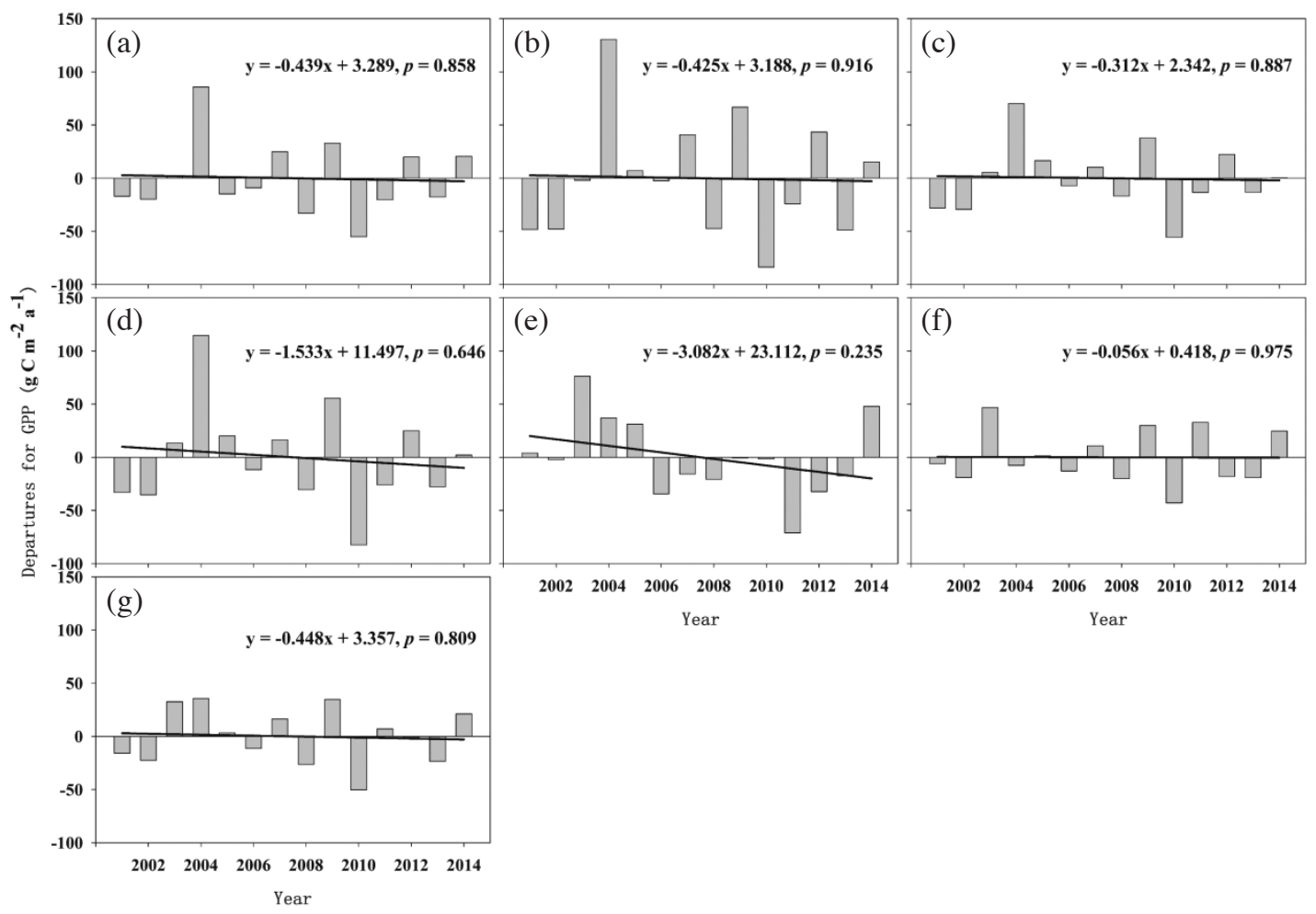

Fig. 4. The departures of mean annual GPP from multiyear means for different biomes in the Yangtze River Delta region during 2001 - 2014; (a) evergreen needle leaf forest, (b) evergreen broadleaf forest, (c) deciduous needle leaf forest, (d) deciduous broad forest, (e) grassland, (f) cropland, and $(\mathrm{g})$ regional annual mean GPP.

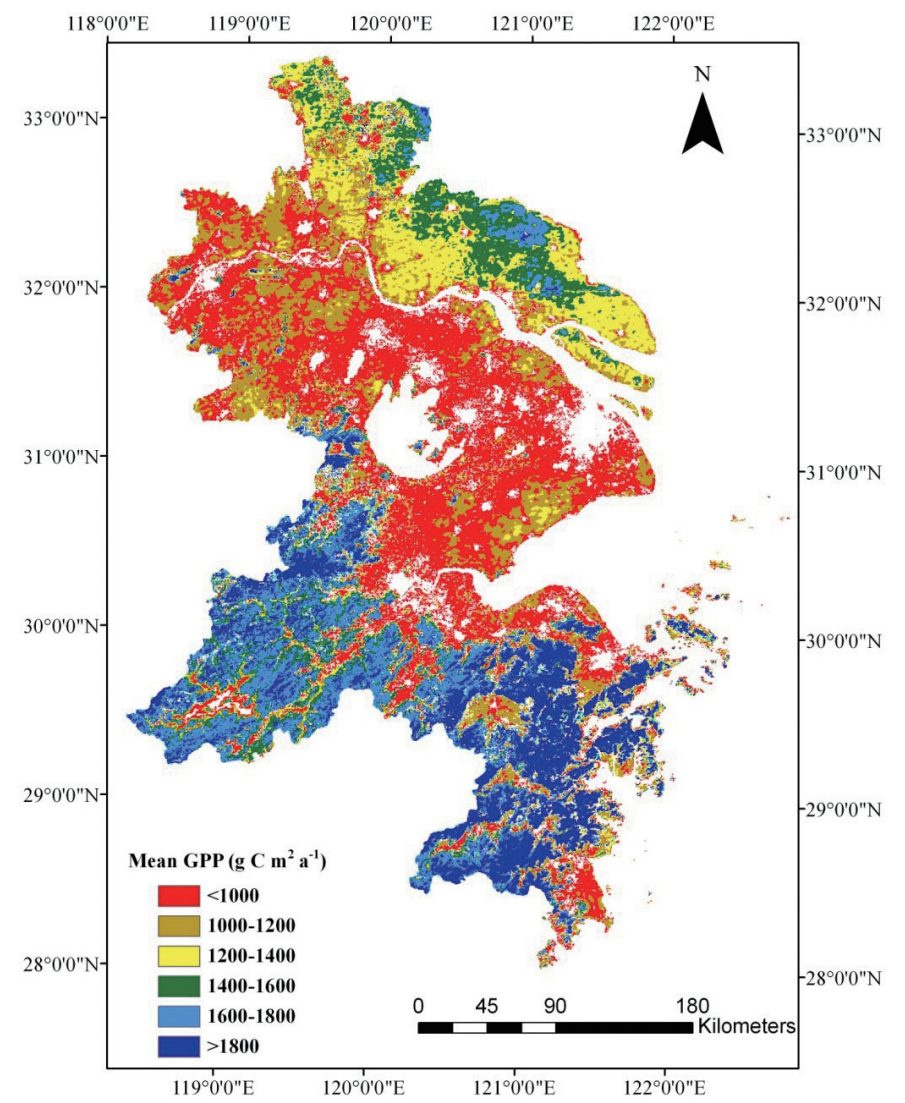

Fig. 5. Spatial distribution of GPP in the Yangtze River Delta during the period 2001 - 2014. 


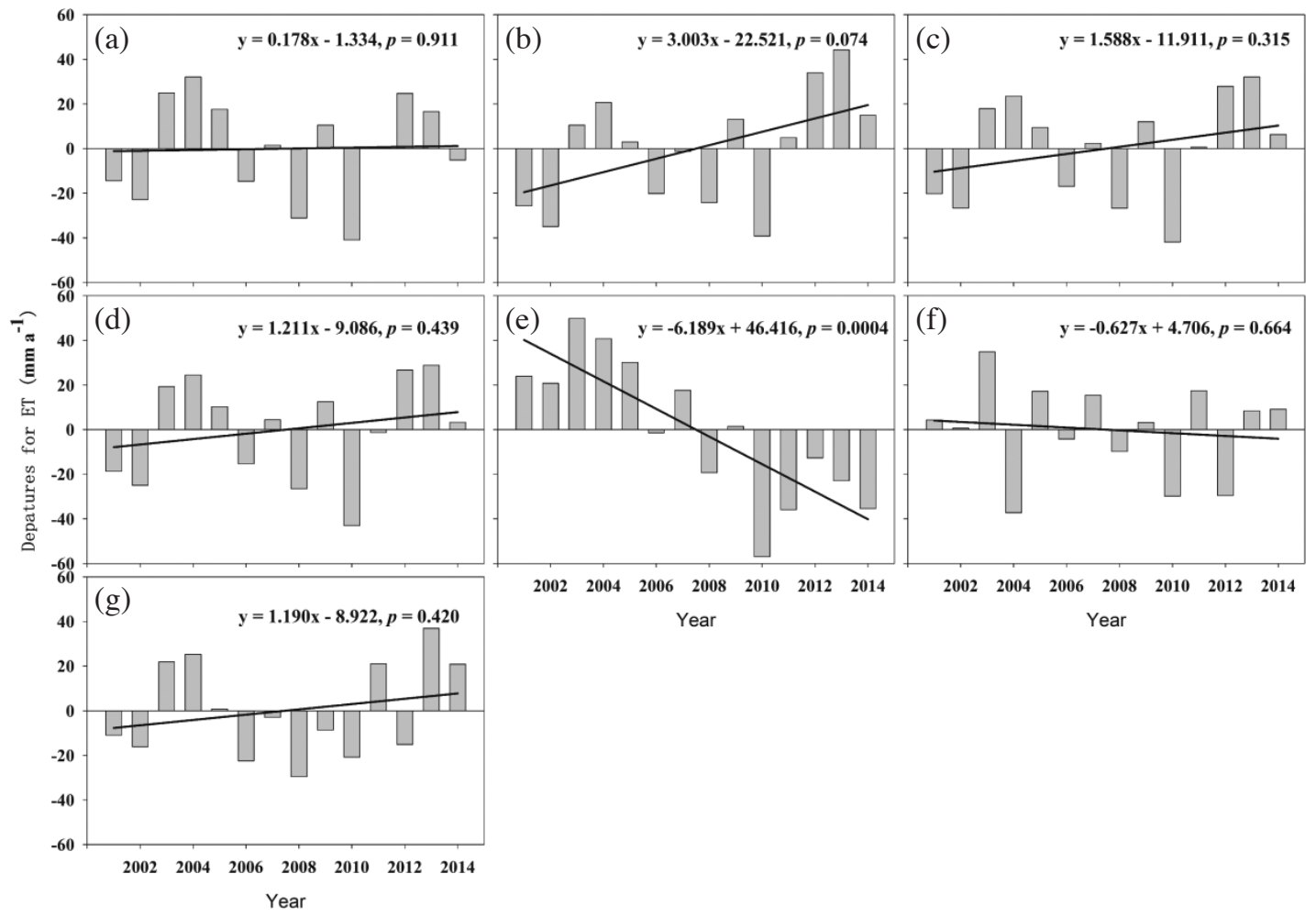

Fig. 6. The departures of mean annual ET from multiyear means for different biomes in the Yangtze River Delta region during 2001 - 2014; (a) evergreen needle leaf forest, (b) evergreen broadleaf forest, (c) deciduous needle leaf forest, (d) deciduous broad forest, (e) grassland, (f) cropland, and $(\mathrm{g})$ regional annual mean GPP.

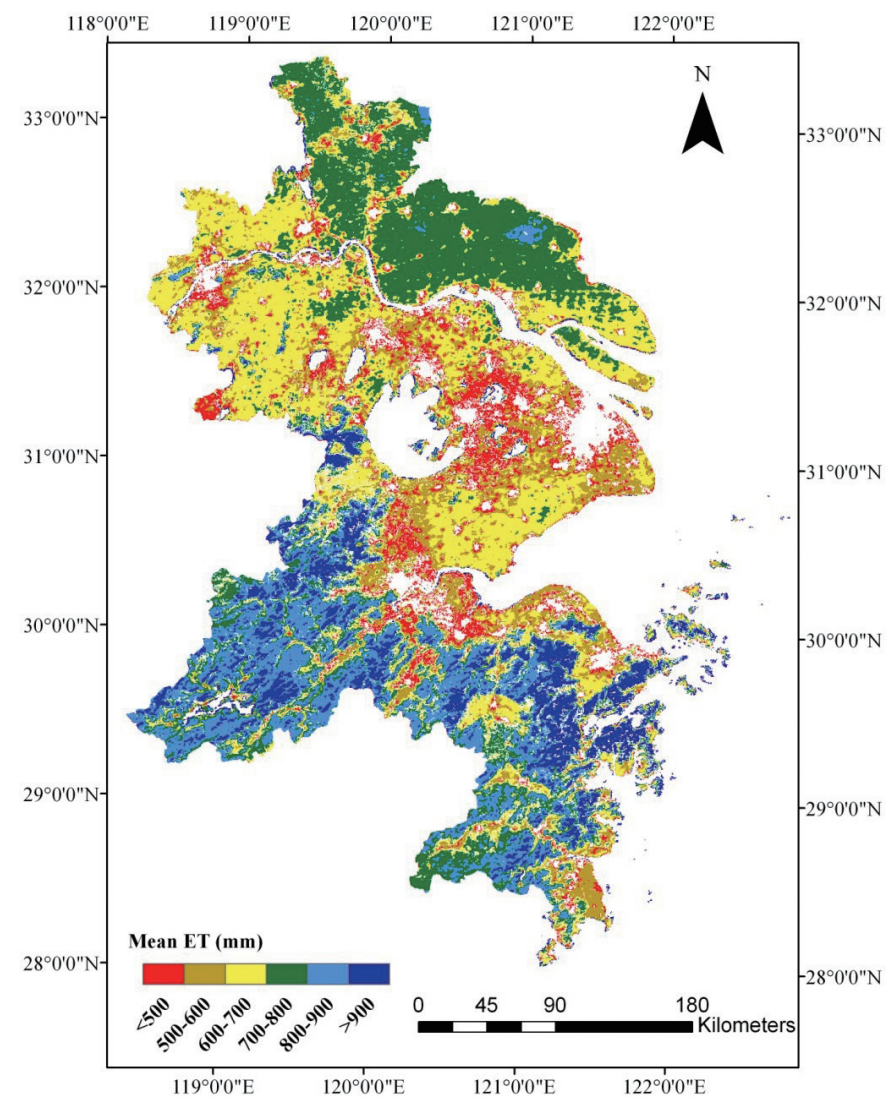

Fig. 7. Spatial distribution of ET in the Yangtze River Delta during the period 2001 - 2014. 


\subsection{Temporal and Spatial Variations of WUE}

In this study, WUE in all forest ecosystems showed a decreasing tendency. In contrast, WUE in cropland and grassland both showed an increasing trend. Among the biomes, evergreen broadleaf forest and grassland achieved a significant level $(\mathrm{p}<0.05)$. In general, the regional WUE showed a decreasing trend (Fig. 8). As WUE was controlled by both GPP and ET, when GPP decreased and ET increased, the WUE inevitably decreased. This was the situation for evergreen broadleaf forest, deciduous needle leaf forest, and deciduous broadleaf forest. The increase in WUE in grassland was due to the decreased ET, for which the rate of decrease was greater than for GPP.

For the spatial distribution of WUE, the maximum value occurred in the south and northwestern part of the YRD region, with WUE greater than $2.0 \mathrm{~g} \mathrm{C} \mathrm{kg}^{-1} \mathrm{H}_{2} \mathrm{O}$. The minimum value was distributed in the middle and northwest of the YRD region, and was smaller than $1.6 \mathrm{~g} \mathrm{C} \mathrm{kg}^{-1} \mathrm{H}_{2} \mathrm{O}$ (Fig. 9).

\subsection{The Annual Average WUE over Vegetation Types}

The annual average WUE over vegetation types ranged from 1.39 - $2.17 \mathrm{~g} \mathrm{C} \mathrm{kg}^{-1} \mathrm{H}_{2} \mathrm{O}$ (Fig. 10). The order was deciduous broadleaf forest $>$ evergreen broadleaf forest $>$ cropland $>$ grassland $>$ evergreen needle leaf forest $>$ deciduous needle leaf forest. Yu et al. (2008) found that WUEs of needle leaf forest were greater than that of broadleaf forest. This difference was mainly caused by the different study scale. In a study by Yu et al. (2008), they focused on the variations of WUE across a transect where the climate conditions among the vegetation types were quite different. However, in our study, we tried to explore the characteristics of WUE at the regional scale where the climate conditions among the vegetation types were comparatively similar. In general, WUE of forest was greater than that of other types and this result was consistent with that of another study (Ito and Inatomi 2012).

\subsection{The Effect of LAI on GPP and ET}

LAI is an important biotic factor for carbon and water cycles, and understanding the response of GPP and ET to LAI can greatly enhance our knowledge of their control processes as well as the ability to predict how climate change may affect carbon and water budgets (Reichstein et al. 2007; $\mathrm{Hu}$ et al. 2008). In our study, GPP increased with increasing LAI across all of the plant function types (Fig. 11), and this pattern has also been proved by other researchers (Flanagan et al. 2002; Xu and Baldocchi 2004; Li et al. 2006; Hashimoto et al. 2012).

Different from GPP, ET only increased with LAI when LAI was less than $2 \mathrm{~m}^{2} \mathrm{~m}^{-2}$ across all of the plant function types, once LAI was larger than $2 \mathrm{~m}^{2} \mathrm{~m}^{-2}$, ET did not continue to increase with LAI (Fig. 12). To a great degree, this
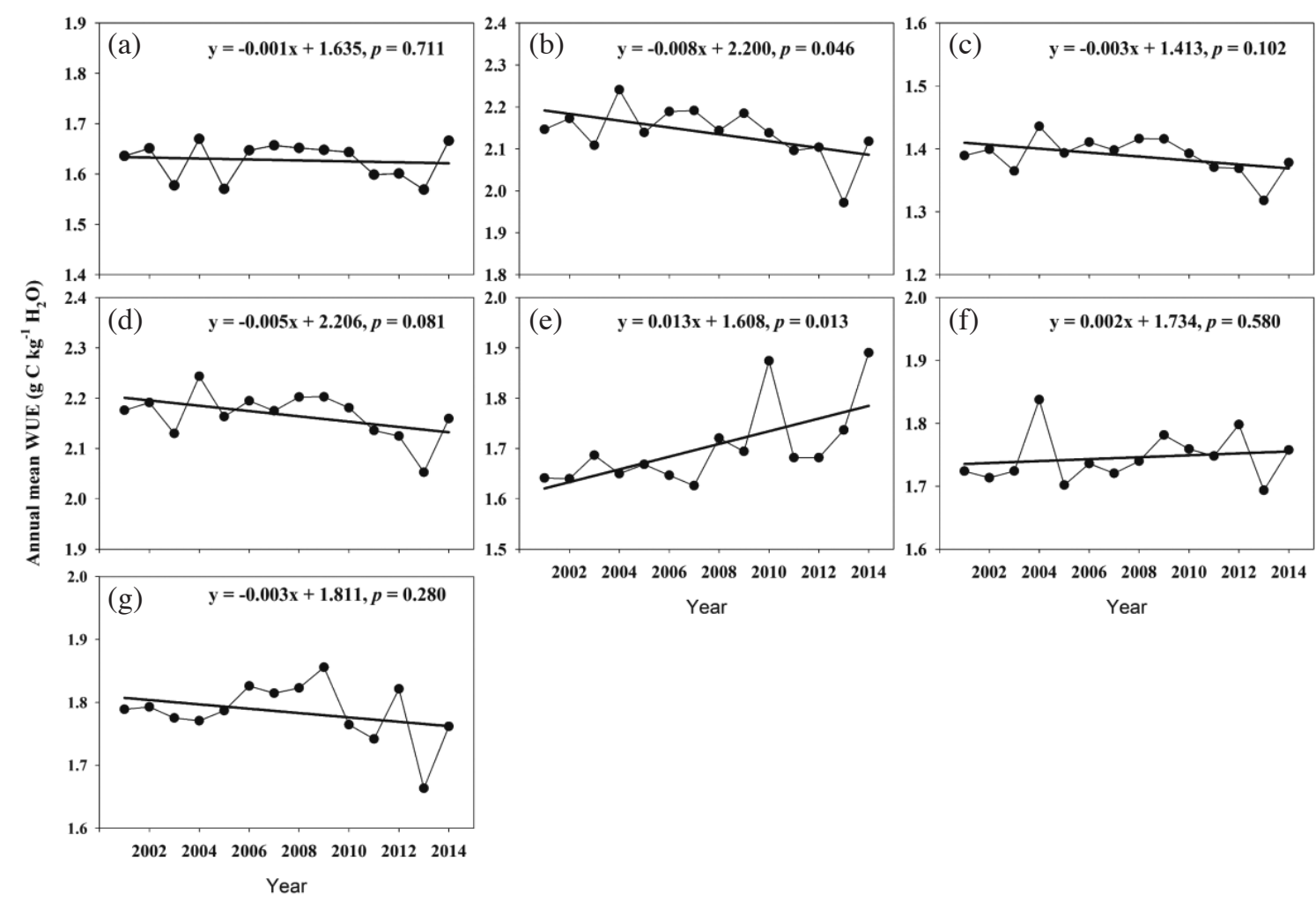

Fig. 8. Tepmporal trends of annual mean WUE for different vegetation types during 2001 - 2014; (a) evergreen needle leaf forest, (b) evergreen broadleaf forest, (c) deciduous needle leaf forest, (d) deciduous broad forest, (e) grassland, (f) cropland, and (g) regional annual mean GPP. 


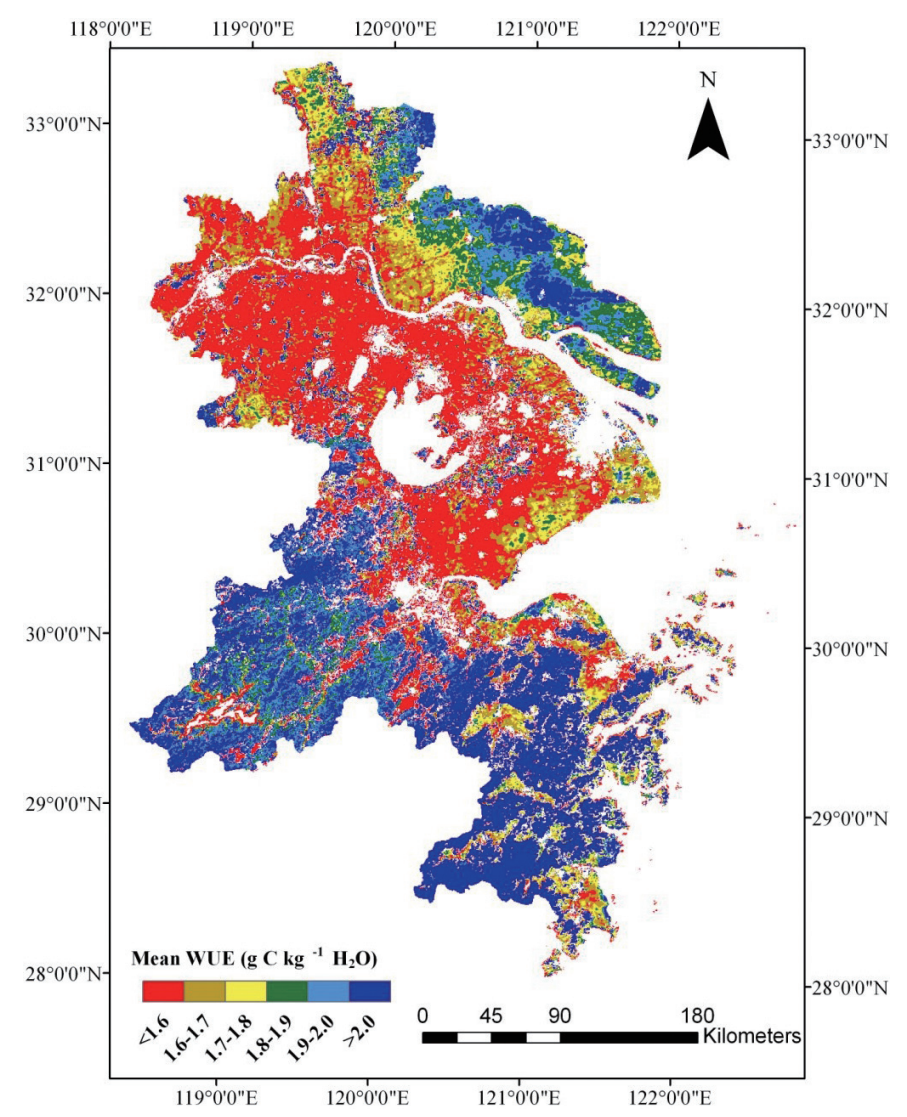

Fig. 9. Spatial distribution of WUE in the Yangtze River Delta during the period 2001 - 2014.

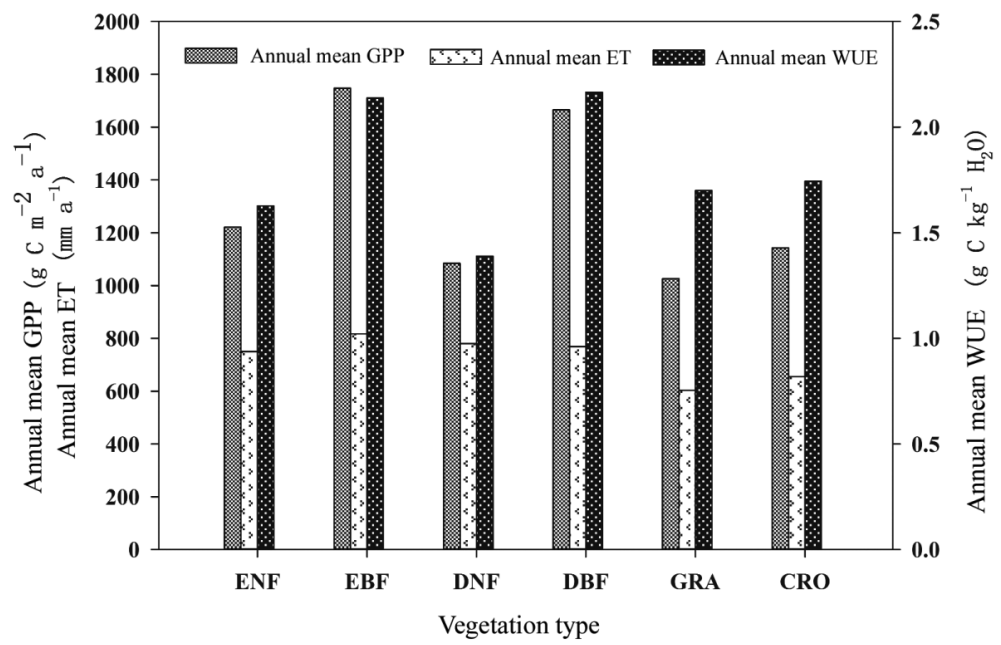

Fig. 10. Simulated annual mean GPP, ET, and WUE of different vegetation types during 2001 - 2014. ENF: evergreen needleleaf forest; EBF: evergreen broadleaf forest; DNF: deciduous needleleaf forest; DBF: deciduous broadleaf forest; GRA: grassland; CRO: cropland. 
(a)

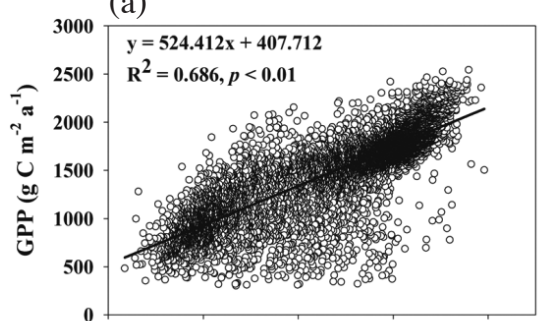

(d)

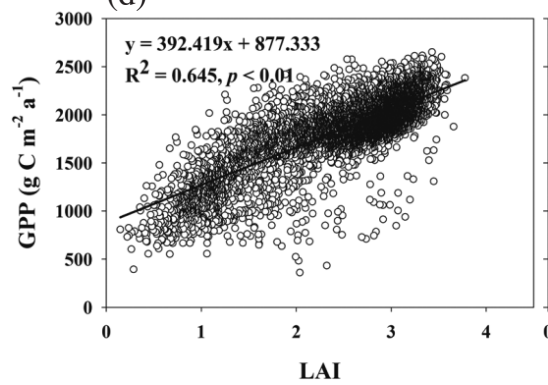

(b)

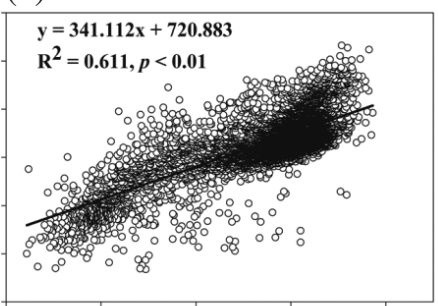

(e)

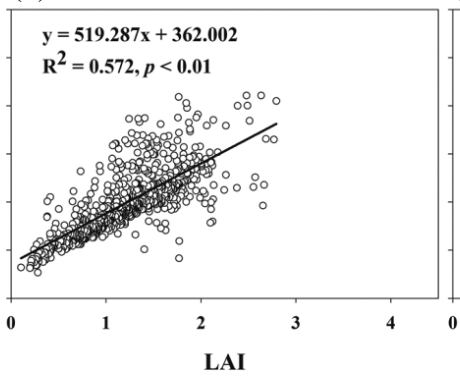

(c)

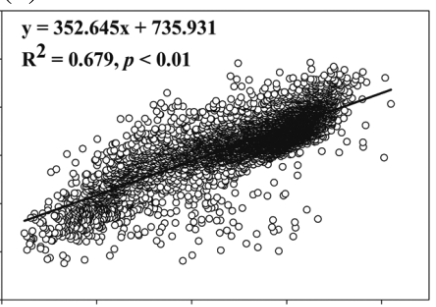

(f)

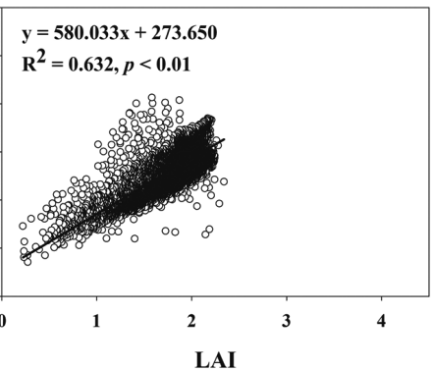

Fig. 11. Relationships between annual mean GPP and annual mean LAI for different biomes in the Yangtze River Delta region; (a) evergreen needle leaf forest, (b) evergreen broadleaf forest, (c) deciduous needle leaf forest, (d) deciduous broadleaf forest, (e) grassland, and (f) cropland.

(a)

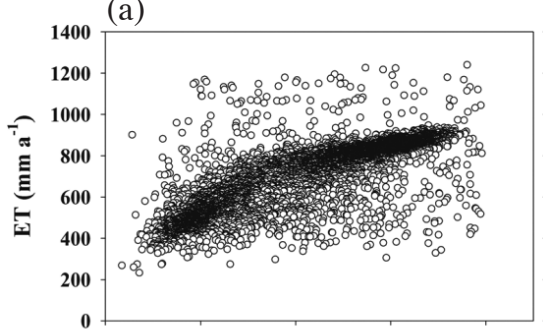

(d)

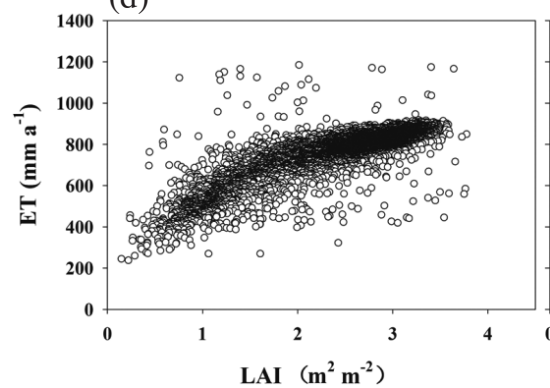

(b)

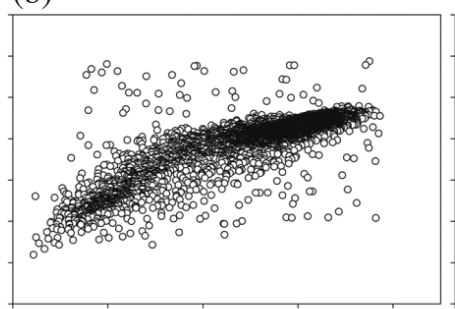

(e)

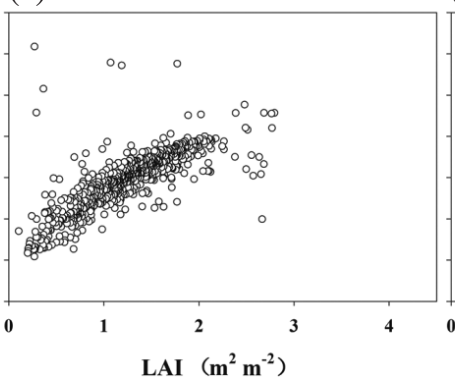

(c)

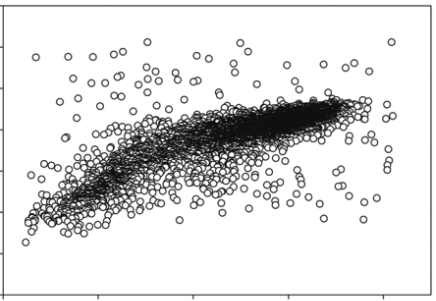

(f)

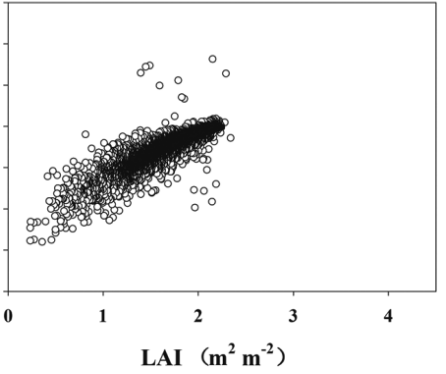

Fig. 12. Relationships between annual mean ET and annual mean LAI for different biomes in the Yangtze River Delta region; (a) evergreen needle leaf forest, (b) evergreen broadleaf forest, (c) deciduous needle leaf forest, (d) deciduous broadleaf forest, (e) grassland, and (f) cropland. 
response pattern was determined by the effect of LAI on transpiration. As the most important component of ET, the way in which transpiration varies with LAI, plays a big role in the effect of LAI on ET. Benyon et al. (2006) found that the increase of changing rate of transpiration slowed down with LAI, and there was a turning point in their relationship. When LAI reached that point, transpiration did not continue to increase with LAI, which is similar to the relationship between ET and LAI found in our study.

\section{FUTURE WORK AND PROSPECT}

In this study, we examined the temporal and spatial variations of GPP, ET, and WUE across plant function types using remote sensing models. It should be noted that a number of models have been developed to simulate the GPP, including the process-based models and the remote sensing models. Which one is superior has been the subject of much debate in recent decades. Recently, Zhang et al. (2016) demonstrated that the VPM model was more reliable than the process-based models based on the spatial distribution and seasonal dynamics of GPP simulated by the VPM model, and sun-induced chlorophyll fluorescence showed better consistency. This enhanced our confidence in using the VPM model. Potential data being used as a benchmark to compare with ET models could also benefit the study of the simulation of ET. The change tendency of GPP, ET, and WUE across plant function types were analyzed in the present study, but further studies are needed to establish the underlying reasons and quantify their respective rates of contribution and finally to predict how climate change may affect carbon and water budgets.

\section{CONCLUSION}

In this study, the vegetation photosynthesis model (VPM) and the revised remote sensing-Penman Monteith (RRS-PM) model were used to characterize the spatialtemporal dynamics of gross primary productivity (GPP) and evapotranspiration (ET) in the Yangtze River Delta (YRD) region. Our predicted GPP and ET results were in the range of those reported by other models, which enhanced confidence in using the remote sensing models. The change tendency of GPP, ET, and WUE across plant function types was different in the present study, so further studies will be needed to establish whether this is determined by climatic factors or other adjustment mechanisms. In the current study, the variation of GPP, ET, and WUE had only been monitored in the last decade or so. It is important for the change tendency to be analyzed in a sustained way in order to gain a better understanding of the impact of climate change. This study demonstrates that LAI is an important biotic factor for carbon and water cycles. Studies using LAI as an input variable to estimate carbon and water fluxes should pay more attention to the quality and accuracy of LAI.

Acknowledgements Funding support partially from the Chinese National Natural Science Foundation (41401385) and science fund project of forestry college, fujian agricultural and forestry university (61201400833). Supported by the program B for Outstanding Ph.D. candidate of Nanjing University.

\section{REFERENCES}

Beer,C.,P.Ciais, M. Reichstein, D. Baldocchi, B.E.Law, D. Papale, J. F. Soussana, C. Ammann, N. Buchmann, D. Frank, D. Gianelle, I. A. Janssens, A. Knohl, B. Köstner, E. Moors, O. Roupsard, H. Verbeeck, T. Vesala, C. A. Williams, and G. Wohlfahrt, 2009: Temporal and among-site variability of inherent water use efficiency at the ecosystem level. Global Biogeochem. Cycles, 23, GB2018, doi: 10.1029/2008gb003233. [Link]

Benyon, R. G., S. Theiveyanathan, and T. M. Doody, 2006: Impacts of tree plantations on groundwater in southeastern Australia. Aust. J. Bot., 54, 181-192, doi: 10.1071/BT05046. [Link]

Buchmann, N. and E. D. Schulze, 1999: Net $\mathrm{CO}_{2}$ and $\mathrm{H}_{2} \mathrm{O}$ fluxes of terrestrial ecosystems. Global Biogeochem. Cycles, 13, 751-760, doi: 10.1029/1999GB900016. [Link]

Chen, C., D. Li, Z. Gao, J. Tang, X. Guo, L. Wang, and B. Wan, 2015: Seasonal and Interannual Variations of Carbon Exchange over a Rice-Wheat Rotation System on the North China Plain. Adv. Atmos. Sci., 32, 13651380, doi: 10.1007/s00376-015-4253-1. [Link]

Chen, J., H. Yan, S. Wang, Y. Gao, M. Huang, J. Wang, and X. Xiao, 2014: Estimation of gross primary productivity in Chinese terrestrial ecosystems by using VPM model. Quaternary Sciences, 34, 732-742, doi: 10.3969/j.issn.1001-7410.2014.04.05. [Link]

Cleugh, H. A., R. Leuning, Q. Mu, and S. W. Running, 2007: Regional evaporation estimates from flux tower and MODIS satellite data. Remote Sens. Environ., 106, 285-304, doi: 10.1016/j.rse.2006.07.007. [Link]

Feng, X., G. Liu, J. M. Chen, M. Chen, J. Liu, W. M. Ju, R. Sun, and W. Zhou, 2007: Net primary productivity of China's terrestrial ecosystems from a process model driven by remote sensing. J. Environ. Manage., 85, 563-573, doi: 10.1016/j.jenvman.2006.09.021. [Link]

Flanagan, L. B., L. A. Wever, and P. J. Carlson, 2002: Seasonal and interannual variation in carbon dioxide exchange and carbon balance in a northern temperate grassland. Global Change Biol., 8, 599-615, doi: 10.1046/j.1365-2486.2002.00491.x. [Link]

Gao, Z. and J. Liu, 2008: Simulation study of China's net primary production. Chin. Sci.Bull., 53, 434-443, doi: 10.1007/s11434-008-0097-8. [Link] 
Gilmanov, T. G., J. F. Soussana, L. Aires, V. Allard, C. Ammann, M. Balzarolo, Z. Barcza, C. Bernhofer, C. L. Campbell, A. Cernusca, A. Cescatti, J. Clifton-Brown, B. O. M. Dirks, S. Dore, W. Eugster, J. Fuhrer, C. Gimeno, T. Gruenwald, L. Haszpra, A. Hensen, A. Ibrom, A. F. G. Jacobs, M. B. Jones, G. Lanigan, T. Laurila, A. Lohila, G.Manca, B. Marcolla, Z. Nagy, K. Pilegaard, K. Pinter, C. Pio, A. Raschi, N. Rogiers, M. J. Sanz, P. Stefani, M. Sutton, Z. Tuba, R. Valentini, M. L. Williams, and G. Wohlfahrt, 2007: Partitioning European grassland net ecosystem $\mathrm{CO}_{2}$ exchange into gross primary productivity and ecosystem respiration using light response function analysis. Agr. Ecosyst. Environ., 121, 93-120, doi: 10.1016/j. agee.2006.12.008. [Link]

Hashimoto, H., W. Wang, C. Milesi, M. A. White, S. Ganguly, M. Gamo, R. Hirata, R. B. Myneni, and R. R. Nemani, 2012: Exploring Simple Algorithms for Estimating Gross Primary Production in Forested Areas from Satellite Data. Rem. Sens., 4, 303-326, doi: 10.3390/ rs4010303. [Link]

Hirata, R., A. Miyata, M. Mano, M. Shimizu, T. Arita, Y. Kouda, S. Matsuura, M. Niimi, T. Saigusa, A. Mori, M. Hojito, O. Kawamura, and R. Hatano, 2013: Carbon dioxide exchange at four intensively managed grassland sites across different climate zones of Japan and the influence of manure application on ecosystem carbon and greenhouse gas budgets. Agric. For. Meteorol., 177, 57-68, doi: 10.1016/j.agrformet.2013.04.007. [Link]

Holben, B. N., 1986: Characteristics of maximumvalue composite images from temporal AVHRR data. Int. J. Remote Sens., 7, 1417-1434, doi: 10.1080/01431168608948945. [Link]

Hu, Z., G. Yu, Y. Fu, X. Sun, Y. Li, P. Shi, Y. Wang, and Z. Zheng, 2008: Effects of vegetation control on ecosystem water use efficiency within and among four grassland ecosystems in China. Global Change Biol., 14, 1609-1619, doi: 10.1111/j.1365-2486.2008.01582.x. [Link]

Ito, A. and M. Inatomi, 2012: Water-use efficiency of the terrestrial biosphere: a model analysis focusing on interactions between the global carbon and water cycles. J. Hydrometeorol., 13, 681-694, doi: 10.1175/JHMD-10-05034.1. [Link]

Jung, M., M. Reichstein, P. Ciais, S. I. Seneviratne, J. Sheffield, M. L. Goulden, G. Bonan, A. Cescatti, J. Chen, R. de Jeu, A. J. Dolman, W. Eugster, D. Gerten, D. Gianelle, N. Gobron, J. Heinke, J. Kimball, B. E. Law, L. Montagnani, Q. Mu, B. Mueller, K. Oleson, D. Papale, A. D. Richardson, O. Roupsard, S. Running, E. Tomelleri, N. Viovy, U. Weber, C. Williams, E. Wood, S. Zaehle, and K. Zhang, 2010: Recent decline in the global land evapotranspiration trend due to limited moisture supply. Nature, 467, 951-954, doi: 10.1038/ nature09396. [Link]

Kang, M., Y. Cai, X. Wang, T. Zha, L. Zhu, Y. Niu, J. Zhou, and Z. Zhang, 2016: Control of evapotranspiration by surface resistance and environmental factors in poplar (Populus $\times$ euramericana) plantations. Acta Ecologica Sinica, 36, 5508-5518, doi: 10.5846/ stxb201502250381. [Link]

Kuglitsch, F. G., M. Reichstein, C. Beer, A. Carrara, R. Ceulemans, A. Granier, I. A. Janssens, B. Koestner, A. Lindroth, D. Loustau, G. Matteucci, L. Montagnani, E. J. Moors, D. Papale, K. Pilegaard, S. Rambal, C. Rebmann, E. D. Schulze, G. Seufert, H. Verbeeck, T. Vesala, M. Aubinet, C. Bernhofer, T. Foken, T. Grünwald, B. Heinesch, W. Kutsch, T. Laurila, B. Longdoz, F. Miglietta, M. J. Sanz, and R. Valentini, 2008: Characterisation of ecosystem water-use efficiency of european forests from eddy covariance measurements. Biogeosciences Discussions, 5, 4481-4519, doi: 10.5194/ bgd-5-4481-2008. [Link]

Li, G. C., 2004: Estimation of Chinese terrestrial net primary production using LUE model and MODIS data. Chinese Academy of Sciences, Beijing.

Li, J., Q. Yu, X. Sun, X. Tong, C. Ren, J. Wang, E. Liu, Z. Zhu, and G. Yu, 2006: Carbon dioxide exchange and the mechanism of environmental control in a farmland ecosystem in North China Plain. Sci. China Ser. D, 49, 226-240, doi: 10.1007/s11430-006-8226-1. [Link]

Li, S.-G., W. Eugster, J. Asanuma, A. Kotani, G. Davaa, D. Oyunbaatar, and M. Sugita, 2008: Response of gross ecosystem productivity, light use efficiency, and water use efficiency of Mongolian steppe to seasonal variations in soil moisture. J. Geophys. Res., 113, G01019, doi: 10.1029/2006jg000349. [Link]

Li, X., S. Liang, G. Yu, W. Yuan, X. Cheng, J. Xia, T. Zhao, J. Feng, Z. Ma, M. Ma, S. Liu, J. Chen, C. Shao, S. Li, X. Zhang, Z. Zhang, S. Chen, T. Ohta, A. Varlagin, A. Miyata, K. Takagi, N. Saiqusa, and T. Kato, 2013: Estimation of gross primary production over the terrestrial ecosystems in China. Ecol. Model., 261-262, 80-92, doi: 10.1016/j.ecolmodel.2013.03.024. [Link]

Liu, C., Z. Zhang, G. Sun, T. Zha, J. Zhu, L. Shen, J. Chen, X. Fang, and J. Chen, 2009: Quantifying evapotranspiration and biophysical regulations of a poplar plantation assessed by eddy covariance and sap-flow methods. J. Plant Ecol., 33, 706-718.

Liu, J., O. J. Sun, H. Jin, Z. Zhou, and X. Han, 2011: Application of two remote sensing GPP algorithms at a semiarid grassland site of North China. J. Plant Ecol., 4, 302-312, doi: 10.1093/jpe/rtr019. [Link]

Liu, Y. B., 2013: The Spatial and Temporal Variations of WaterUse Efficiency in China's Terrestrial Ecosystems Simulated Using Remote Sensing and a Process-based Model. Ph.D. Thesis, Nanjing University, Nanjing. 
Liu, Z., L. Wang, and S. Wang, 2014: Comparison of different GPP models in China using MODIS image and ChinaFLUX data. Rem. Sens., 6, 10215-10231, doi: 10.3390/rs61010215. [Link]

Mu, Q., F. A. Heinsch, M. Zhao, and S. W. Running, 2007: Development of a global evapotranspiration algorithm based on MODIS and global meteorology data. Remote Sens. Environ., 111, 519-536, doi: 10.1016/j. rse.2007.04.015. [Link]

Mu, Q., M. Zhao, and S. W. Running, 2011: Improvements to a MODIS global terrestrial evapotranspiration algorithm. Remote Sens. Environ., 115, 1781-1800, doi: 10.1016/j.rse.2011.02.019. [Link]

Ponton, S., L. B. Flanagan, K. P. Alstad, B. G. Johnson, K. Morgenstern, N. Kljun, T. A. Black, and A. G. Barr, 2006: Comparison of ecosystem water-use efficiency among Douglas-fir forest, aspen forest and grassland using eddy covariance and carbon isotope techniques. Global Change Biol., 12, 294-310, doi: 10.1111/j.13652486.2005.01103.x. [Link]

Reichstein, M.,P.Ciais, D. Papale, R. Valentini, S. Running, N. Viovy, W. Cramer, A. Granier, J. Ogée, V. Allard, M. Aubinet, C. Bernhofer, N. Buchmann, A. Carrara, T. Grünwald, M. Heimann, B. Heinesch, A. Knohl, W. Kutsch, D. Loustau, G. Manca, G. Matteucci, F. Miglietta, J. M. Ourcival, K. Pilegaard, J. Pumpanen, S. Rambal, S. Schaphoff, G. Seufert, J. F. Soussana, M. J. Sanz, T. Vesala, And M. Zhao, 2007: Reduction of ecosystem productivity and respiration during the European summer 2003 climate anomaly: A joint flux tower, remote sensing and modelling analysis. Global Change Biol., 13, 634-651, doi: 10.1111/j.13652486.2006.01224.x. [Link]

Ruimy, A., P. G. Jarvis, D. D. Baldocchi, and B. Saugier, 1995: $\mathrm{CO}_{2}$ Fluxes over Plant Canopies and Solar Radiation: A Review. In: Begon, M. and A. H. Fitter (Eds.), Advances in Ecological Research, Volume 26, Academic Press, 1-68, doi: 10.1016/S00652504(08)60063-X. [Link]

Schymanski, S. J., M. L. Roderick, M. Sivapalan, L. B. Hutley, and J. Beringer, 2008: A canopy-scale test of the optimal water-use hypothesis. Plant Cell Environ., 31, 97-111, doi: 10.1111/j.1365-3040.2007.01740.x. [Link]

Tang, X., H. Li, A. R. Desai, Z. Nagy, J. Luo, T. E. Kolb, A. Olioso, X. Xu, L. Yao, W. Kutsch, K. Pilegaard, B. Köstner, and C. Ammann, 2014: How is water-use efficiency of terrestrial ecosystems distributed and changing on Earth? Sci. Rep., 4, doi: 10.1038/srep07483. [Link]

Tian, J., H. Su, S. Chen, X. Sun, and Q. Chen, 2012: SpatialTemporal variations of evapotranspiration in China mainland in recent 20 years. Resource Science, 34, 1277-1286.
Tong, X. J., J. Li, Q. Yu, and Z. Qin, 2009: Ecosystem water use efficiency in an irrigated cropland in the North China Plain. J. Hydrol., 374, 329-337, doi: 10.1016/j. jhydrol.2009.06.030. [Link]

Wang, F., H. Jiang, and X. Zhang, 2015: Spatial-temporal dynamics of gross primary productivity, evapotranspiration, and water-use efficiency in the terrestrial ecosystems of the Yangtze River Delta region and their relations to climatic variables. Int. J. Remote Sens., 36, 2654-2673, doi: 10.1080/01431161.2015.1041618. [Link]

Wang, F., H. Jiang, X. Chen, and X. Niu, 2016: Bamboo Forest Water Use Efficiency in the Yangtze River Delta Region, China. Terr. Atmos. Ocean. Sci., 27, 981989, doi: 10.3319/TAO.2016.02.07.01(Hy). [Link]

Wang, H., G. Jia, C. Fu, J. Feng, T. Zhao, and Z. Ma, 2010: Deriving maximal light use efficiency from coordinated flux measurements and satellite data for regional gross primary production modeling. Remote Sens. Environ.,114,2248-2258, doi: 10.1016/j.rse.2010.05.001. [Link]

Wang, J. B., 2004: Chinese terrestrial net ecosystem production model applied remote sensing data. Zhejiang University, Hangzhou.

Wei, Q. H., H. L. He, M. Liu, L. Zhang, G. R. Yu, C. C. Min, H. M. Wang, and Y. Liu, 2012a: Modeling Evapotranspiration and Its Components in Qianyanzhou Plantation Based on Remote Sensing Data. J. Natural Resources, 27, 778-789.

Wei, Y., S. Gao, X. Zhang, S. Geng, X. Zhao, Z. Jiang, and Y. Wang, 2012b: Source Area in-FLUX Measurements by FSAM Model over the Populus deltoides Plantation in Yueyang. Scientia Silvae Sinicae, 48, 16-21, doi: 10.11707/j.1001-7488.20120203. [Link]

Wever, L. A., L. B. Flanagan, and P. J. Carlson, 2002: Seasonal and interannual variation in evapotranspiration, energy balance and surface conductance in a northern temperate grassland. Agric. For. Meteorol., 112, 31 49, doi: 10.1016/s0168-1923(02)00041-2. [Link]

Wu, J., Y. Ding, G. Wang, Y. Yusuke, and K. Jumpei, 2006: Evapotranspiration of intercropping field in an artifical oasis in arid region. Transactions of the Chinese Society of Agricultural Engineering, 22, 16-20.

Wu, S., S. Zhou, D. Chen, Z. Wei, L. Dai, and X. Li, 2014: Determining the contributions of urbanisation and climate change to NPP variations over the last decade in the Yangtze River Delta, China. Sci. Total Environ., 472, 397-406, doi: 10.1016/j.scitotenv.2013.10.128. [Link]

Wu, W., S. Wang, X. Xiao, G. Yu, Y. Fu, and Y. Hao, 2008: Modeling gross primary production of a temperate grassland ecosystem in Inner Mongolia, China, using MODIS imagery and climate data.Sci. China Ser.D, 51, 1501-1512, doi: 10.1007/s11430-008-0113-5. [Link] 
Xiang, Y., Z. Xiao, S. Liang, J. Wang, and J. Song, 2014: Validation of Global LAnd Surface Satellite (GLASS) leaf area index product. J. Rem. Sens., 18, 573-596.

Xiao, X., D. Hollinger, J. Aber, M. Goltz, E. A. Davidson, Q. Zhang, and B. Moore, 2004a: Satellite-based modeling of gross primary production in an evergreen needleleaf forest. Remote Sens. Environ., 89, 519-534, doi: 10.1016/j.rse.2003.11.008. [Link]

Xiao, X., Q. Zhang, B. Braswell, S. Urbanski, S. Boles, S. Wofsy, B. Moore, and D. Ojima, 2004b: Modeling gross primary production of temperate deciduous broadleaf forest using satellite images and climate data. Remote Sens. Environ., 91, 256-270, doi: 10.1016/j. rse.2004.03.010. [Link]

Xiao, X., Q. Zhang, S. Saleska, L. Hutyra, P. De Camargo, S. Wofsy, S. Frolking, S. Boles, M. Keller, and B. Moore, 2005: Satellite-based modeling of gross primary production in a seasonally moist tropical evergreen forest. Remote Sens. Environ., 94, 105-122, doi: 10.1016/j.rse.2004.08.015. [Link]

Xiao, Z., S. Liang, J. Wang, P. Chen, X. Yin, L. Zhang, and J. Song, 2013: Use of general regression neural networks for generating the GLASS leaf area index product from time-series MODIS surface reflectance. IEEE Trans. Geosci. Remote Sensing, 52, 209-223, doi: 10.1109/TGRS.2013.2237780. [Link]

$\mathrm{Xu}, \mathrm{L}$. and D. D. Baldocchi, 2004: Seasonal variation in carbon dioxide exchange over a Mediterranean annual grassland in California. Agric. For. Meteorol., 123, 7996, doi: 10.1016/j.agrformet.2003.10.004. [Link]

Xu, X., G. Zhou, S. Liu, H. Du, L. Mo, Y. Shi, H. Jiang, Y. Zhou, and E. Liu, 2013: Implications of ice storm damages on the water and carbon cycle of bamboo forests in southeastern China. Agric. For. Meteorol., 177, 3545, doi: 10.1016/j.agrformet.2013.04.005. [Link]

Yan, H., Y. Fu, X. Xiao, H. Q. Huang, H. He, and L. Ediger, 2009: Modeling gross primary productivity for winter wheat-maize double cropping system using MODIS time series and $\mathrm{CO}_{2}$ eddy flux tower data. Agr. Ecosyst. Environ., 129, 391-400, doi: 10.1016/j. agee.2008.10.017. [Link]

Yu, G. R., Q. F. Wang, and J. Zhuang, 2004: Modeling the water use efficiency of soybean and maize plants under environmental stresses: application of a synthetic model of photosynthesis-transpiration based on stomatal behavior. J. Plant Physiol., 161, 303-318, doi: 10.1078/0176-1617-00972. [Link]

Yu, G. R., X. Song, Q. Wang, Y. Liu, D. Guan, J. Yan, X. Sun, L. Zhang, and X. Wen, 2008: Water-use efficiency of forest ecosystems in eastern China and its relations to climatic variables. New Phytologist, 177, 927-937, doi: 10.1111/j.1469-8137.2007.02316.x. [Link]

Yuan, W., S. Liu, G. Zhou, G. Zhou, L. L. Tieszen, D. Baldocchi, C. Bernhofer, H. Gholz, A. H. Goldstein, M.
L. Goulden, D. Y. Hollinger, Y. Hu, B. E. Law, P. C. Stoy, T. Vesala, and S. C. Wofsy, 2007: Deriving a light use efficiency model from eddy covariance flux data for predicting daily gross primary production across biomes. Agric. For. Meteorol., 143, 189-207, doi: 10.1016/j.agrformet.2006.12.001. [Link]

Yuan, W., S. Liu, G. Yu, J. M. Bonnefond, J. Chen, K. Davis, A. R. Desai, A. H. Goldstein, D. Gianelle, F. Rossi, A. E. Suyker, and S. B. Verma, 2010: Global estimates of evapotranspiration and gross primary production based on MODIS and global meteorology data. Remote Sens. Environ., 114, 1416-1431, doi: 10.1016/j. rse.2010.01.022. [Link]

Zeng, Z., S. Piao, X. Lin, G. Yin, S. Peng, P. Ciais, and R. B. Myneni, 2012: Global evapotranspiration over the past three decades: Estimation based on the water balance equation combined with empirical models. Environ. Res. Lett., 7, 014026, doi: 10.1088/17489326/7/1/014026. [Link]

Zhang, F., W. Ju, J. Chen, S. Wang, G. Yu, Y. Li, S. Han, and J. Asanuma, 2010: Study on evapotranspiration in east Asia using the BEPS ecological model. J. Natural Resources, 25, 1596-1606, doi: 10.11849/ zrzyxb.2010.09.019. [Link]

Zhang, Y., X. Xiao, C. Jin, J. Dong, S. Zhou, P. Wagle, J. Joiner, L. Guanter, Y. Zhang, G. Zhang, Y. Qin, J. Wang, and B. Moore, 2016: Consistency between sun-induced chlorophyll fluorescence and gross primary production of vegetation in North America. Remote Sens. Environ., 183, 154-169, doi: 10.1016/j. rse.2016.05.015. [Link]

Zhao, L. W. and X. B. Ji, 2010: Quantification of transpiration and evaporation over agricultural field using the FAO-56 dual crop coefficient approach - A case study of the maize field in an oasis in the middlestream of the Heihe River Basin in northwest China. Scienntia Agricultura Sinica, 43, 4016-4026.

Zhao, M. and S. W. Running, 2010: Drought-Induced Reduction in Global Terrestrial Net Primary Production from 2000 Through 2009. Science, 329, 940-943, doi: 10.1126/science.1192666. [Link]

Zheng, H., Q. F. Wang, Y. N. Li, and X. J. Zhu, 2013: Characteristics of evapotranspiration in an alpine shrub meadow in Haibei, Qinghai of Northwest China. Chinese Journal of Applied Ecology, 24, 3221-3228.

Zhou, G. Y., X. H. Wei, Y. P. Wu, S. G. Liu, Y. H. Huang, J. H. Yan, D. Q. Zhang, Q. M. Zhang, J. X. Liu, and Z. Meng, 2011: Quantifying the hydrological responses to climate change in an intact forested small watershed in Southern China. Global Change Biol., 17, 3736-3746, doi: 10.1111/j.1365-2486.2011.02499.x. [Link]

Zhu, Q., H. Jiang, C. Peng, J. Liu, X. Wei, X. Fang, S. Liu, G. Zhou, and S. Yu, 2011: Evaluating the effects of future climate change and elevated $\mathrm{CO}_{2}$ on the water 
use efficiency in terrestrial ecosystems of China. Ecol. Model., 222, 2414-2429, doi: 10.1016/j.ecolmodel.2010.09.035. [Link]

Zhu, X. J., G. R. Yu, Q. F. Wang, Z. M. Hu, H. Zheng, S. G. Li, X. M. Sun, Y. P. Zhang, J. H. Yan, H. M. Wang, F.
H. Zhao, J. H. Zhang, P. L. Shi, Y. N. Li, L. Zhao, F. W. Zhang, and Y. B. Hao, 2015: Spatial variability of water use efficiency in China's terrestrial ecosystems. Global Planet. Change, 129, 37-44, doi: 10.1016/j.gloplacha.2015.03.003. [Link] 